\title{
Bulkfill Techniques with Intermediate Layer to Marginal Adaptation Restoration of Class II Composite Resin
}

\author{
Mochammad Raidjffan Zulkarnaen Tabona, ${ }^{1}$ Adioro Soetojo, ${ }^{2}$ Ira Widjiastuti, ${ }^{2}$ \\ ${ }^{1}$ Undergraduate Student of Dental Medicine, Faculty of Dental Medicine, Airlangga University, Surabaya, Indonesia \\ ${ }^{2}$ Staff of Departement of Conservative Dentistry, Faculty of Dental Medicine, Airlangga University, Surabaya, Indonesia
}

\begin{abstract}
Background: Dental caries is a hard tissue disease caused by bacterial metabolic activity that causes demineralization, teeth that have caries should be filled in order to function again. One of the restorative materials closer to natural teeth is composite resin because it is the same colour as natural teeth and is easy to shape. As for the placement technique, bulkfill is also used because it is more time-efficient, and irradiation is accompanied by applying the restoration material in one batch. However, the bulkfill technique often causes micro-leakage of dental caries deposition. The intermediate layer is an intermediate layer used to prevent micro-leakage at the edges of the restoration as a base layer for restoration to create a good adaptation before applying packable composite resin. Therefore, bulkfill coating technique with the intermediate layer can reduce the risk of microleakage. Purpose: To describe the bulkfill technique with an intermediate layer against marginal adaptation with class II composite resin restorations. Review: The literature sources used in the preparation of the articles through several databases with descriptions. More journals say that micro-leakage in class II cavity deposition with the intermediate layer technique is better than the bulkfll technique because the intermediate layer technique has better bond strength than the bulkfill technique. If the Bulkfill technique is modified with the Intermediate layer technique, it can show good correlation and internal adaptation. Conclusion: Bulkfill technique with an intermediate layer against marginal adaptation with class II composite resin restorations can reduce the microleakage rate by reducing the polymerization's shrinkage strain.
\end{abstract}

Keywords: dental caries; resin komposit; Bulkfill; intermediate layer

Correspondence: Adioro Soetojo, Department of Conservative Dentistry, Faculty of Dental Medicine, Universitas Airlangga, Jl. Mayjen. Prof. Dr. Moestopo No.47 Surabaya, 60132 Indonesia. Email: adioroprof@gmail.com

\section{INTRODUCTION}

Dental caries is a hard tissue disease caused by bacterial metabolism in plaque which causes demineralization due to interactions between microorganism products, saliva and substrate. Dental caries treatment can be done using a filling. One of the materials for filling the tooth cavity is composite resin ${ }^{1,2}$.

Composite resin is a material that is closer to natural tooth colour and is the choice for restoration. Composite resin is a dental restoration material consisting of organic components (resin) that form a matrix, inorganic fillers, interfacial materials, initiator systems, stabilizers (inhibitors) and pigments. The good aesthetic value is why composite resin is widely used in the community because it is the same colour as natural teeth. It is insoluble, low heat conductor and easy to manipulate ${ }^{1,2}$.

According to the Black classification in Class II (MOD) caries cavity, resin composite restorations are more prone to failure ${ }^{3,4}$. The procedure has limited access and vision, conventional composite resins weaken with increasing cervical length, and are particularly prone to poor polymerization ${ }^{5}$.

The bulkfill technique is often chosen because it is more time-efficient with placing the restorative material into the entire cavity filled in one filling, followed by irradiation. The use of the composite bulkfill technique, which can be applied with the bulk technique, can polymerize in deeper cavities, effectively resists polymerization shrinkage, is durable, is not easy to fracture, and has good dimensional stability $^{6}$. However, the results showed that the bulkfill technique had a higher microleakage value than incremental technique ${ }^{6}$.

Dentists widely use flowable composite resin as an intermediate layer. The intermediate layer is an intermediate layer used to prevent micro-leakage at the edges of the restoration. Dentists use the composite resin as an intermediate layer as a base layer for restorations to create a good adaptation before applying packable composite resin ${ }^{7,8}$. The incremental technique resulted 
in less microleakage than the bulk load on conventional composite resins ${ }^{8}$.

Microleakage is the undetectable movement of fluids, molecules and bacterial ions in the micro-gap between the cavity wall and the restorative material. The leading cause of micro-leakage at the composite resin restoration at the cavity edge is that the composite cannot cover the edges entirely due to shrinkage and contraction during the polymerization of the composite resin plus contamination with saliva or tissue fluids, so that adaptation to the cavity wall is reduced ${ }^{9}$. Microleakage can cause hypersensitivity in the restored tooth, discolouration of the cavity margins and restorations, recurrent caries, pulp inflammation and failure of endodontic treatment ${ }^{10}$.

Resin composites replace amalgam as a restorative material. However, its use has problems with resin-based materials, especially (caries, materials and tooth fractures). Polymer chain imbalances form polymer networks. The reduction in tissue mobility causes further shrinkage and tension in the resin composite and cavity margins ${ }^{11}$.

The contraction properties due to the resin composite's polymerization reaction caused by the increased concentration of pressure on the surface that binds the tooth tissue can cause poor adaptation of the restoration edges ${ }^{11}$. Techniques to reduce polymerization contraction problems include additional fill techniques with an elastic modulus such as dentin as a glass ionomer cement or flowable composite resin ${ }^{11}$.

The use of flowable composite resin as an intermediate layer in overcoming stress in the composite resin layer's contraction has drawbacks ${ }^{11}$. Composite flowable material technology as a substitute for dentin has developed, such as Dentsply's SDR тM (Smart Dentine Replacement), which aims to reduce the volume rate of the composite material's contraction flowed by modifying 4-polymerized, urethane di-methacrylate (UDMA) monomers ${ }^{11}$.

Natasha and Suprastiwi (2017) stated that composites that can flow as an intermediate layer affect reducing micro-leakage in the gingival wall of the proximal composite restoration. Feitosa et al. (2018) stated that a large carious lesion on the distal surface of the second left maxillary premolar using a composite. After 7 days of operation, the restoration was conducted out, and the restoration was evaluated based on updated USPHS and FDI parameters ${ }^{12}$.

Therefore, an analysis is needed that will be outlined in this review to examine the similarities and differences in the results of studies related to bulkfill and intermediate layer techniques and modifications between the two of marginal adaptation with Class II composite resin restorations.

\section{REVIEW}

Caries is a tooth hard tissue disease caused by a microorganism activity in a carbohydrate characterized by demineralization of tooth hard tissue, which is then followed by damage to the organic material. As a result, there is a bacterial invasion and the spread of the infection to the periapical tissues, which can cause pain. However, given the possibility of remineralization occurring, at a very early stage, the disease can be stopped ${ }^{13}$. The four main factors that cause dental caries are the host, agent (microflora), and environment (substrate). The occurrence of dental caries is due to these three factors' synergy and is supported by the fourth factor, namely time ${ }^{14}$.

Class II dental caries are the cavity on the posterior teeth' approximal surface on the smooth surface/mesial and distal lesions usually under the contact point that is difficult to clean. Can be classified as MO (mesio-occlusal), DO (distoocclusal) and MOD (mesio-occlusal-distal) cavities ${ }^{15}$.

Composite is a modification of methacrylate or acrylate with other materials to form a product with different properties and structures. Composite resins have three main components, namely matrix, filler and coupling agents ${ }^{16}$. Composite resins can be used for anterior and posterior tooth restorations, directly or indirectly, corebuild-up, pit and fissure sealants, bonding for orthodontic brackets, coating metal crowns and fixed dentures, and repairing porcelain restorations ${ }^{17}$.

Composite resins based on viscosity are composite packable and flowable bulk fill. For Class I and V restorations, bulkfill flowable composites are indicated and are commonly used for fissure sealants because they have a low viscosity, making it easier to flow. For restorations that are difficult to reach, but have low strength and marginal fit, bulkfill flowable composites are also recommended ${ }^{18}$. Meanwhile, packable bulkfill is stronger because it has a higher viscosity and better marginal fit ${ }^{19}$.

Flowable composite resin has several advantages: the ability to wet the tooth surface, ensure penetration into any irregularities, form a layer with minimal thickness, repair and eliminate incoming air, radio-opaqueness, and available in various colours and high flexibility ${ }^{17}$.

Composite resins are divided based on the filling technique, namely the intermediate layer technique and the bulkfill technique. The technique that is often used to reduce microleakage in direct composite resin restorations is the use of flowable composite resin as the intermediate layer. Flowable composite resin has a low viscosity so it is expected to reach hard-to-reach parts of the prepared cavity. Application of the intermediate layer at the base of the restoration before packable composite resin can result in good adaptation and does not leave micro-leakage.

The bulkfill technique is a restoration technique with one laying of the material until it fills the entire cavity before radiating it. This technique has been known for a long time, but from the research, it is known that it has a higher microleakage value than using the incremental technique ${ }^{20}$.

Dentin bonding is a material used to bond restorative materials which tend to be hydrophobic with hydrophilic teeth. Shrinkage or shrinkage in composite resins can be reduced by applying a bonding agent before the composite resin. The bonding material provides a strong bond between the composite restoration and the tooth 
structure to withstand mechanical forces and stresses in the polymerization process. Dentin bonding consists of etches, primers, adhesives, solvents, initiators, and fillers ${ }^{18}$.

Microleakage is the movement of fluids, molecules, and bacterial particles that are not scientifically observed between the cavity wall and the restorative material added in the micro gap $(10-6 \mu \mathrm{m})^{21}$.

Factors that cause micro-gap formation can include poor adhesion, variable temperature, contraction force, inadequate humidity control, and masticatory strength. Micrometer leaks lead to the entry of bacteria, accelerating the sensitivity due to the hydrodynamic interface phenomenon. Microleakage also leads to discolouration, damaged restoration, secondary caries, and possible pulp pathosis ${ }^{21}$.

The vibrational motion of the atom and the interatomic distance (bonding) increases when the material experiences an increase in temperature, increasing the expansion volume. The thermal expansion coefficient $\alpha$, defined as the change in length per unit from the original length of a material when the temperature rises by $1^{\circ} \mathrm{C}$, explains this increase $(1 \mathrm{~K})^{18}$.

Resins have polymerization or shrinkage properties that can create interface gaps, thereby affecting biomechanics and marginal adaptation of composites to cavities. Polymerization shrinkage is one factor that plays a role in adhesion failure, micro-leakage, and the formation of secondary caries ${ }^{22}$. Polymerization shrinkage is influenced by several factors, including shape, duration of exposure, increment thickness, a light unit system used, cavity diameter, cavity location, radiation distance to the composite resin's surface, substrate polymerized using light, type of filler, and temperature.

Hygroscopic expansion in the restoration results from the resin's absorption, which increases its volume. The absorption of water by this resin can compensate for polymerization shrinkage and produce relaxation from internal stresses. Hygroscopic expansion in hydrophilic materials can absorb water beyond polymerization shrinkage. According to several studies, hygroscopic expansion can reduce microleakage in composite restorations ${ }^{22-25}$.

Several studies have shown that acids can change the physical properties of composite resins that are in an acidic environment for a certain period. The solution's acidity can hydrolyze the coupling agent (silane) so that it can trigger the release of filler particles and dissolve the resin matrix ${ }^{26}$. Composite resins in an acidic environment have high solubility properties, so they can cause surface erosion, material degradation, increase wear, hardness, and the degradation of composite resins can also include loss of material due to erosion processes. Acidic drinks with a $\mathrm{pH}$ below the critical $\mathrm{pH}$ to demineralize enamel (4.5-5.5) can cause erosion. Carbonated drinks are one of the non-alcoholic drinks that have a high acidity level. The most considerable carbonated drinks content is carbonic acid which has a $\mathrm{pH}$ of 2.37 or a concentration of $56.693 \mathrm{mg} / \mathrm{mL}$. Composite resins are said to be degraded due to exposure to acids in artificial saliva with low $\mathrm{pH}^{27}$.
The composite resin's inability to adapt adequately to the cavity edge can lead to micro-leakage in the Class II cavity, namely the formation of internal gaps along the gingival margins. This is due to the lack of enamel at the edge of the gingival wall so that only the composite resin bonds to the dentin in that region. Furthermore, caused by polymerization contraction due to contraction stress that pulls the interfacial bond between the tooth and the composite, causing a gap. Dentin has unique anatomy and composition, so the mechanism of adhesion to dentin is more complicated than that of enamel.

\section{DISCUSSION}

Composite resin is a popular restorative material because it has good aesthetic value and physical-mechanical properties, is stable in long-term use and can be used in almost all classifications of G.V Black caries lesions ${ }^{18}$. Many innovations in composite materials have been developed, one of which is by simplifying restoration techniques while maintaining their physical properties. The bulkfill technique is a composite fill that can be applied down to a depth of $4 \mathrm{~mm}$, thereby shortening the processing time. Other characteristics of the bulkfill technique with composite bulkfill materials are effective against polymerization shrinkage, durable, not easy to fracture, and has good dimensional stability ${ }^{6}$. Packable bulkfill composite resin has a high viscosity so that it can adapt quickly to dentin and has high mechanical strength making it suitable for use in posterior teeth. It was found that the microleakage of packable bulkfill composites was greater than that of flowable composites with intermediate layer fills ${ }^{28}$.

The success factors and efficiency of tooth restoration include good marginal adaptation. Marginal adaptation can also be called marginal accuracy. Good marginal adaptation is characterized by the space between the tooth structure and the restorative material that is fixed / narrow, does not undergo significant changes ${ }^{29,30}$. Marginal itself means a tooth preparation's surrounding or edge $\mathrm{e}^{31}$, and it is possible to determine the marginal adaptation by the distance between the restorative material and the tooth structure wall. This evaluation can be done at 600 times the magnification under an electron microscope ${ }^{32}$.

Microleakage can be caused by dimensional changes and poor adaptation to the cavity walls ${ }^{21}$. Micro-fissures can reduce the density of the restoration margins, the development of hypersensitivity to the restored teeth, discolouration of the cavity margins and restorations, secondary caries, pulp inflammation, and failure of endodontic treatment. This shrinkage is a big problem, especially in Class II restorations (Figure 1).

Bulkfill fill resins can be carried up to $4 \mathrm{~mm}$ thick, and the fluid characteristics allow proper resin flow and can fill without any space. This method (Figure 2) can incorporate photoactive groups that allow light which can affect the thickness. SDR technology has a polymerization modulator to help monomers form a more flexible polymer network 


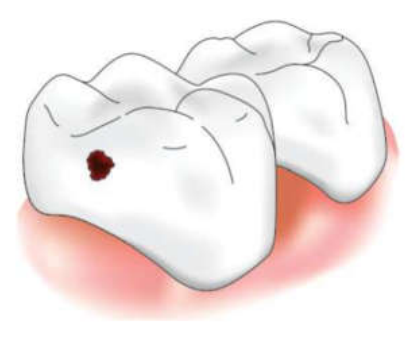

Figure 1. Class II caries on the proximal surface of molars and premolars. ${ }^{33}$.

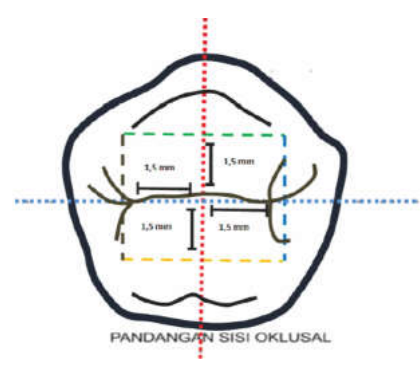

Figure 2. Method of determination of cavity design ${ }^{34}$.

more slowly and inhibits volumetric shrinkage. One of the qualities of bulkfill resin is that it significantly reduces cup deflection during light-curing compared to conventional resin restorations performed by the incremental oblique technique. Using bulkfill resin in class II as a study showed a reduction in valve deflection compared with multiple oblique restorations. The reduction occurs due to deflection of the material inserted horizontally in the gingivaoclusal direction, reducing the valve's length and increasing the deflection.

Compared to traditional resins, the polymerization shrinkage and curing rate of bulkfill resin will flow based on volume levels. By applying a thickness of $4 \mathrm{~mm}$, bulk filling occurs with ample polymerization. Compared to traditional resin composites, bulkfill resins have smaller polymerization volumes at lower shrinkage and lower stresses. Various manufacturers suggest adding bulkfill resin to a thickness of $4 \mathrm{~mm}$ to have a more accurate polymerization. The cavity depth was observed using a periodontal probe to ensure the bulkfill was applied so that the thickness did not exceed $4 \mathrm{~mm}$ (Figure 3).

Flowable resins from bulkfill have less filler than traditional ones. The proximal feature of Class II restoration carried out with flowable bulkfill resins did not occur with traditional resins. This damage causes proximal, long-term loss due to material loss, better absorption of water and resin hydrolysis due to material degradation. After one week, post-treatment sensitivity occurred in the patient. The clinical trial findings indicate that sensitivity occurs within the first three weeks due to changes in temperature and occlusal forces. Sensitivity during the restorative procedure is not purely arbitrary since it may be linked to irrigation during tooth preparation to excessive dentin drying during the bonding procedure and may also be

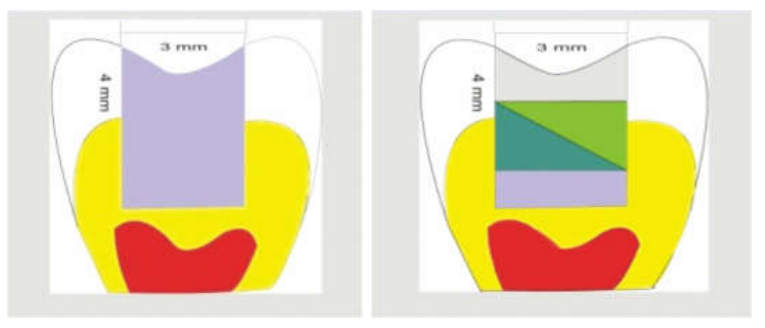

Figure 3. Bulkfill resinfilling up to $4 \mathrm{~mm}$ deep. A.Simultaneously into a $4 \mathrm{~mm}$ deep cavity. B. Oblique incrementally. ${ }^{34}$

linked to the patient's psychological state's short-term sensitivity.

A cavity with a higher free surface and a smaller volume than every composite layer is required to minimize the leakage. Maximizing the free surface would likely increase the reduction of tension by reducing material movement. The resulting composite resin thickness can be characterized by light immersion and a decrease in light that reaches a significant part of the cavity area. The increase of the bond layer in resin composites has a bond strength characteristic. When the gap is thin and repaired, light can enter the bottom of the cavity, while the catalyst is strengthened, the first addition of the resin composite can polymerize more efficiently. The rise in the translucency with composites of bulkfill resin seems to be using relatively thick resin composites in bulkfill filling techniques ${ }^{11}$.

Shrinkage in strain can be encountered by the internal adaptation of Class II restorations, and the elasticity modulus can be taken into account when choosing materials for the intermediate layer. Bulkfill with an intermediate layer shows high correlation and internal adaptation increases. Resin modification has more significant shrinkage strain, distinct structure, bonding of dentine, and regulatory reaction mechanisms than composites of resin. The elastic or bending modulus can be a calculation of the material's strength. When the marginal leakage reached resin composite restorations with different bending moduli compared, there was no relationship. Several studies have shown that low elasticity modulus does not minimize the polymerization of microleakage or shrinkage stress. The intermediate layer can not function as a stress breaking layer, but rather as a tension producing layer, depending on its physical properties.

The reduction in polymerization shrinkage did not show a significant difference in the use of non-modified bulkfill. However, the results showed a significant impact on the modification of bulk fill with resin composites between shrinkage strain, flexural module and polymerization shrinkage stress (PS), indicating the ability to protect the thickness of the layer and prevent the occurrence of shrinkage or polymerization strain. Compared to conventional methods, the benefit of using bulkfill layer resin is that it decreases the micro-leakage rate. This is due to a decrease in the polymerization stresses transmitted to the interface between the intermediate and tooth layers. Some bulkfill resin composites show comparatively low 
shrinkage and flexural modulus, which may result in lower polymerization. The results of several studies show that bulkfill modification with an intermediate layer has been shown to reduce the rate of microleakage by reducing polymerization strain shrinkage.

\section{CONCLUSION}

Bulk fill technique with an intermediate layer against marginal adaptation with the restoration of Class II composite resin can reduce the microleakage rate by reducing the shrinkage strain from polymerization.

The bulkfill technique with the intermediate layer showed good correlation and improved internal adaptation. Modified resin has a higher shrinkage strain, a different composition, dentin bonding and regulatory reaction mechanisms than unmodified resin composites.

\section{REFERENCES}

1. Ramayanti S, Purnakarya I. Peran Makanan terhadap Kejadian Karies Gigi. J Kesehat Masy. 2013;

2. Haines et al, goleman, daniel; boyatzis, Richard; Mckee A. Perbedaan daya antibakteri pasta gigi herbal dan non herbal terhadap bakteri Lactobacillus acidophilus. J Chem Inf Model. 2019;

3. Ferrario VF, Sforza C, Serrao G, Dellavia C, Tartaglia GM. Single tooth bite forces in healthy young adults. J Oral Rehabil. 2004;

4. Dejak B, Młotkowski A. A comparison of stresses in molar teeth restored with inlays and direct restorations, including polymerization shrinkage of composite resin and tooth loading during mastication. Dent Mater. 2015;

5. Benetti AR, Havndrup-Pedersen C, Pedersen MK, Honoré D, Pallesen U. Bulk-fill resin composites: Polymerization contraction, depth of cure, and gap formation. Oper Dent. 2015;

6. van Ende A, de Munck J, Lise DP, van Meerbeek B. Bulk-fill composites: A review of the current literature. J Adhes Dent. 2017;19(2):95-109.

7. Baroudi K, Rodrigues JC. Flowable resin composites: A systematic review and clinical considerations1. Baroudi K, Rodrigues JC. Flowable resin composites: A systematic review and clinical considerations. J Clin Diagnostic Res. 2015;9(6):ZE18-24. J Clin Diagnostic Res. 2015;

8. Li Q, Jepsen S, Albers HK, Eberhard J. Flowable materials as an intermediate layer could improve the marginal and internal adaptation of composite restorations in Class-Vcavities. Dent Mater. 2006;

9. Lokhande NA, Padmai AS, Rathore VPS, Shingane S, Jayashankar DN, Sharma U. Effectiveness of flowable resin composite in reducing microleakage - an in vitro study. J Int oral Heal JIOH. 2014;

10. Sencimen M, Ortakoglu K, Aydn C, Aydintug YS, Ozyigit A, Ozen $\mathrm{T}$, et al. Is endodontic treatment necessary during coronectomy procedure? J Oral Maxillofac Surg. 2010;

11. Flury S, Hayoz S, Peutzfeldt A, Hüsler J, Lussi A. Depth of cure of resin composites: Is the ISO 4049 method suitable for bulk fill materials? Dent Mater. 2012;

12. Feitosa FA, Esteves SR, Crastechini E, Ferraz Caneppele T,
Bresciani E. Bulk fill resin restoration: Clinical considerations and case report. Int J Dent Oral Sci. 2018;

13. Kidd E, Fejerskov O. Changing concepts in cariology: Forty years on. Dent Update. 2013;

14. Haryani W. Sikap Pelihara Diri Gigi dan Mulut Sebagai Upaya Pencegahan Dini Terjadinya Karies Gigi Anak. Bul War Kampus. 2015;10(September):26-7.

15. Iriantoro DND, Dewi C, Fitriani D. Klasifikasi pada Penyakit Dental Caries Menggunakan Gabungan K-Nearest Neighbor dan Algoritme Genetika. J Pengemb Teknol Inf dan Ilmu Komput. 2018;2(8):2926-33.

16. Anusavice KJ. Phillips' Science of Dental Materials (Anusavice Phillip's Science of Dental Materials). Elsevier Saunders. 2013.

17. Manappallil J. Basic Dental Materials. Basic Dental Materials. 2016.

18. Annusavice KJ, Antonson SA, Brantley WA. Phillips' Science of Dental Materials. 2013.

19. Miletic V, Pongprueksa P, De Munck J, Brooks NR, Van Meerbeek B. Curing characteristics of flowable and sculptable bulk-fill composites. Clin Oral Investig. 2017;

20. Sakaguchi R, Ferracane J, Powers J. Craig's Restorative Dental Materials, Fourteenth Edition. Fourteenth. Vol. 226, British dental journal. Elsevier Inc.; 2019.9 p.

21. NA L, AS P, VP R, Shingane S, DN J, Sharma U, et al. Effectiveness of flowable resin composite in reducing microleakage - an in vitro study. J Int Oral Heal. 2014;6(3):111-4.

22. Rosales-leal JI, María C, González-moreira H, Cabrerizovílchez MA. Effect of Hygroscopic Expansion of Resin Filling on Interfacial Gap and Sealing : A Confocal Microscopy Study. 2013;15(5):423-30.

23. Rahimian-imam S, Ramazani N, Fayazi MR. Marginal Microleakage of Conventional Fissure Sealants and SelfAdhering Flowable Composite as Fissure Sealant in Permanent Teeth. 2015;430-5.

24. Casselli DSM, Faria-E-Silva AL, casselli H, Martins LRM. Marginal adaptation of class $\mathrm{V}$ composite restorations submitted to thermal and mechanical cycling. J Appl Oral Sci. 2013;21(1):68-73.

25. Ozel Bektas O, Eren D, Akin EG, Akin H. Evaluation of a self-Adhering flowable composite in terms of micro-shear bond strength and microleakage. Acta Odontol Scand. 2013;71(3-4):541-6.

26. Han L, Okamoto A, Fukushima M, Okiji T. Evaluation of Flowable Resin Composite Surfaces Eroded by Acidic and Alcoholic Drinks. 2008;27(3).

27. Saraswati W, Kumalasari DPA, Soetojo A. Microleakage difference between total-etch and self-etch bonding in bulk fill packable composite restoration after carbonic acid immersion. Dent J (Majalah Kedokt Gigi). 2019;192(32):192-6.

28. Jackson R. Posterior Composites and the New Bulk-Fill Materials. Insid Dent. 2014;10(8):68-75.

29. Papadiochou S, Pissiotis AL. Marginal adaptation and CADCAM technology: A systematic review of restorative material and fabrication techniques. Journal of Prosthetic Dentistry. 2018.

30. Syahrial. Journal Of Syiah Kuala Dentistry. J Syiah Kuala Dent Soc. 2018;

31. Budimulia B, Aryanto M. Microleakage of bulkfill flowable composite resin at various irradiation distances $\mathrm{J}$ Kedokt Gigi Univ Padjadjaran. 2018;

32. Naveen T, Dhanraj M, Jain AR. Marginal adaptation of composite resin with different dentin bonding agents in Class V restorations. Drug Invent Today. 2018; 
33. Garg N, Garg A. Textbook of Operative Dentistry. Stomatol EDU J. 2014;

34. Permana DP, Sujatmiko B, Yulianti R. Perbandingan tingkat kebocoran mikro resin komposit bulk-filldengan teknik penumpatan oblique incremental dan bulk. Maj Kedokt Gigi Indones. 2016;
35. Sukmana BI, Budhy TI, Ardani IGAW. The potentiation of Mangifera casturi bark extract on interleukin- $1 \beta$ and bone morphogenic protein-2 expressions during bone remodeling after tooth extraction. Dent J (Majalah Kedokt Gigi). 2017 Mar;50(1):36-42. 